\title{
ANALISIS KOMITMEN DAN KOMPETENSI SUMBER DAYA MANUSIA TERHADAP PERKEMBANGAN KOPERASI SIMPAN PINJAM BAHARI JAYA DI KOTA JAMBI
}

\author{
Oleh : Ade Taufan, Naskah \\ Sekolah Tinggi Keguruan Dan Ilmu Pendidikan YPM Bangko \\ E-mail : adetaufan707@yahoo.com, E-mail : naskah20@gmail.com
}

\begin{abstract}
Abstrack
This study aims to find empirical evidence, which shows the commitment to influence the development of savings and loan cooperatives and show the competency of human resources (HR) affecting the development of Bahari Jaya savings and loan cooperatives in Jambi City. This type of research is qualitative descriptive research that describes the problems examined in sentence form using assumptions and theoretical studies. This research conducted data collection using library study methods, interviews, and field observations. The results of the analysis can be concluded that the Savings and Loans Cooperative was established aimed at providing opportunities for its members to obtain loans easily and with low interest. Savings and loan cooperatives also try to prevent members from engaging in the bondage of loan sharks when they need some money, by intensifying savings and regulating lending money at the lowest interest rates.
\end{abstract}

Keywords : Commitment and competence of human resources and savings and loan cooperatives

\begin{abstract}
Abstrak
Penelitian ini bertujuan untuk menemukan bukti empiris, yang menunjukkan Komitmen mempengaruhi Perkembangan koperasi simpan pinjam dan menunjukkan Kompetensi Sumber Daya Manusia (SDM) mempengaruhi Perkembangan koperasi simpan pinjam Bahari Jaya di Kota Jambi. Jenis penelitian ini yaitu penelitian deskriptif kualitatif yang menggambarkan permasalahan yang diteliti dalam bentuk kalimat menggunakan asumsi dan kajian teori. Penelitian ini dilakukan pengumpulan data dengan menggunakan metode studi kepustakaan, wawancara, dan observasi ke lapangan. Hasil analisis tersebut dapat disimpulkan bahwa Koperasi Simpan Pinjam didirikan bertujuan untuk memberi kesempatan kepada anggotanya untuk memperoleh pinjaman dengan mudah dan dengan bunga ringan. Koperasi simpan pinjam juga berusaha untuk mencegah para anggotanya agar tidak terlibat dalam jeratan kaum lintah darat pada waktu mereka memerlukan sejumlah uang, dengan jalan menggiatkan tabungan dan mengatur pemberian pinjaman uang dengan bunga yang serendah-rendahnya.
\end{abstract}

Kata kunci : Komitmen dan kompetensi sumber daya manusia dan koperasi simpan pinjam 


\section{PENDAHULUAN}

Koperasi menurut Menteri Negara Koperasi Usaha Kecil dan Menengah RI No: 129/KEP/M.KUKM/XI/2002 adalah badan usaha yang beranggotakan orang seorang/ badan hukum. Koperasi sekaligus sebagai gerakan ekonomi rakyat yang berdasarkan asas kekeluargaan. Anggota merupakan faktor utama yang harus diperhatikan dan dilayani, sebab keberadaan anggota berpengaruh pada kelangsungan hidup dan keberhasilan suatu koperasi. Pelayanan terhadap anggota merupakan hal yang terpenting didalam koperasi, karena kekuatan koperasi ada pada anggota. Jika koperasi mampu memberikan pelayanan yang memuaskan pada anggota, maka akan mendorong anggota untuk dapat meningkatkan partisipasinya didalam koperasi, sehingga tujuan koperasi akan dapat tercapai sesuai target.

Prinsip - prinsip koperasi antara lain : 1) Prinsip keanggotaan sukarela dan terbuka, 2) Prinsip pengendalian oleh anggota secara demokratis, 3) Prinsip Partisipasi ekonomi anggota artinya anggota menyumbang secara adil terhadap modal koperasi, 4) Prinsip Otonomi dan kemandirian artinya koperasi secara mandiri membangun dan dikendalikan oleh anggota, 5) Prinsip Pendidikan dan Pelatihan, mengandung makna koperasi menyelenggarakan pendidikan dan latihan bagi anggota, pengurus, manajer dan karyawan, 6) Prinsip kerjasama, 7) Prinsip kepedulian terhadap komunitas artinya koperasi bekerja untuk pembangunan.

Koperasi dibagi menjadi beberapa yaitu koperasi konsumen, koperasi produsen, koperasi jasa, dan koperasi simpan pinjam. Era modern ini sedang tumbuh dan berkembang koperasi simpan pinjam. Hal tersebut dikarenakan kebutuhan akan kebutuhan modal yang cukup tinggi dari usaha kecil dan menengah dan karena sulitnya mendapat bantuan permodalan melalui sistem kredit dari perbankan. Menurut Undang Undang Republik Indonesia nomor 17 tahun 2012 tentang perkoperasian, Koperasi Simpan Pinjam adalah koperasi yang menjalankan usaha simpan pinjam sebagai satu-satunya usaha. Koperasi bertujuan meningkatkan kesejahteraan anggota pada khususnya dan masyarakat pada umumnya, sekaligus sebagai bagian yang tidak terpisahkan dari tatanan perekonomian nasional yang demokratis dan berkeadilan. Koperasi simpan pinjam mempunyai fungsi menghimpun dana dari masyarakat dalam bentuk simpanan deposito berjangka dan 
tabungan. Koperasi simpan pinjam juga memberikan pinjaman kepada masyarakat dalam bentuk kredit.

Dengan adanya koperasi simpan pinjam yang memberikan pinjaman kepada masyarakat, maka perlu dilakukan pengawasan dan kontrol yang benar agar tidak keluar dari prinsip-prinsip koperasi dan tujuan serta asas dari koperasi. Oleh karena itu, koperasi sebagai badan usaha memerlukan pengukuran kinerja yang tepat sebagai dasar untuk menentukan efektifitas kegiatan usahanya terutama efektifitas operasional, bagian organisasi dan karyawannya berdasarkan sasaran, standar dan kriteria yang telah ditetapkan (Mulyadi, 2001).

\section{Perkembangan Koperasi}

mengalami pasang surut dari waktu ke waktu, sampai dengan bulan Desember 2013, jumlah koperasi di Kota Jambi sebanyak 743 koperasi yang terdiri dari 740 Koperasi Primer dan 3 Koperasi Sekunder dengan katagori sebagai berikut :

1) Koperasi Aktif sebanyak 193 Unit Koperasi yaitu koperasi yang sehat kelembagaan, sehat usaha dan sehat mental serta melaksanakan Rapat Anggota Tahunan setiap tahunnnya. 2) Koperasi pasif sebanyak 501 Unit Koperasi yaitu koperasi yang aktifitas usahanya berjalan, akan tetapi tidak rutin melaksanakan Rapat Anggota Tahunan / RAT. 3) Koperasi Beku sebanyak 49 Unit koperasi yaitu Koperasi yang Badan Hukum masih terdaftar di Dinas Koperasi, UMKM Kota Jambi, akan tetapi aktifitas usaha, kepengurusan dan anggotanya tidak ada lagi.

Jumlah anggota sampai saat ini sebanyak 12.204 orang, dengan jumlah modal sendiri koperasi sebesar Rp. 70.255.411.730,-, sedangkan modal luar sebesar Rp. 81.034.712.520, pada umumnya koperasi di Kota Jambi menjalankan usaha simpan pinjam, konsumsi, jasa dan produksi dengan volume usaha sebesar Rp. 136.591.080.896,- sedangkan untuk SHU sebesar Rp. 14.434.636.621,- yang SHU berkisar Rp. 5 Juta sampai 2,8 Milyar.

Permasalahan dan tantangan yang sering dihadapi koperasi terletak pada kemampuan Sumber Daya manusia (SDM) dalam mengelola koperasi, rendahnya kualitas SDM, rendahnya tingkat motivasi dalam bekerja, dan permodalan yang terbatas. Hal yang perlu diperhatikan untuk mengetahui maju atau mundur sebuah koperasi yaitu ketersediaan modal. Ketika modal koperasi tinggi maka kinerja koperasi akan mengalami peningkatan 
begitu juga sebaliknya ketika modal koperasi rendah, maka kinerja koperasi akan mengalami penurunan. Modal koperasi diperoleh dari simpanan wajib, simpanan pokok, dana hibah, dan cadangan dan dari pihak ketiga. Pihak ketiga meliputi swasta, investor, Bank, dan lembaga keuangan lainnya.

Dalam koperasi simpan pinjam dibutuhkan komitmen untuk menunjukkan keyakinan dan dukungan yang kuat terhadap nilai dan sasaran yang ingin dicapai oleh organisasi. Komitmen organisasi yang kuat dalam diri individu akan menyebabkan individu berusaha keras mencapai tujuan organisasi sesuai dengan tujuan dan kepentingan organisasi. Individu yang memiliki tingkat komitmen organisasi tinggi akan memiliki pandangan positif dan lebih berusaha berbuat yang terbaik demi kepentingan organisasi. Sebaliknya, bagi individu dengan komitmen organisasi rendah akan mempunyai perhatian yang rendah pada pencapaian tujuan organisasi, dan cenderung berusaha memenuhi kepentingan pribadi. Individu tersebut tidak memiliki keinginan untuk menjadikan organisasinya ke arah yang lebih baik (Ikhsan dan Ane, 2007).
Faktor lain yang perlu ditingkatkan bagi para karyawan dan pengurus koperasi simpan pinjam Bahari Jaya adalah Kompetensi Sumber Daya Manusia (SDM). Pelayanan terhadap anggota merupakan hal yang terpenting didalam koperasi, karena kekuatan koperasi ada pada anggota. Jika koperasi mampu memberikan pelayanan yang memuaskan pada anggota, maka akan mendorong anggota untuk dapat meningkatkan partisipasinya didalam koperasi, sehingga tujuan koperasi akan dapat tercapai sesuai target. Hal ini tentunya perlu mendapatkan perhatian terutama jika koperasi ingin mampu bersaing dengan lembaga keuangan lainnya. Seleksi para pekerja dan pengurus di koperasi perlu diawasi walaupun memang dalam hal ini terdapat keterbatasan koperasi mengingat pengurus koperasi berasal dari anggota koperasi itu sendiri. Langkah pasti yang perlu diambil adalah pendidikan dan pelatihan para pekerja dan pengurus koperasi dalam hal ini selain melatih skill mereka juga mencoba menambahkan personal qualities mereka.

Kompetensi SDM Koperasi Simpan Pinjam Bahari Jaya dalam penelitian ini memfokuskan pada tiga hal pokok yaitu : Pengetahuan (Knowladge), Keterampilan 
(Skill) dan Kemampuan (Ability), Pengetahuan (Knowladge), merupakan penguasaan ilmu dan teknologi yang dimiliki seseorang, dan diperoleh melalui proses pembelajaran serta pengalaman selama kehidupannya. Indikator pengetahuan (knowladge) dalam hal ini adalah, pengetahuan manajemen bisnis, pengetahuan produk atau jasa, pengetahuan tentang konsumen, promosi dan strategi pemasaran. Keterampilan (Skill), adalah kapasitas khusus untuk memanipulasi suatu objek secara fisik. Indikator keterampilan meliputi: keterampilan berinovasi, berkomunikasi, kerjasama dan organisasi, pengawasan, keuangan, administrasi dan akuntansi. Kemampuan (Ability), adalah kapasitas seorang individu untuk mengerjakan berbagai tugas dalam suatu pekerjaan. Indikator kemampuan meliputi : kemampuan mengelola bisnis, mengambil keputusan, memimpin, mengendalikan, berinovasi, situasi dan perubahan lingkungan bisnis. Komponen terpenting untuk menggerakan kegiatan koperasi yaitu keseriusan, kreativitas, kesetiaan serta keahlian yang dimiliki anggota. Ada semacam hubungan timbal balik antara keseriusan anggota dalam menggerakan koperasi dengan kegiatan koperasi yang memuaskan anggota dimana anggota yang aktif membuat kinerja koperasi menjadi baik dan pada gilirannya membuat kesejahteraan anggota meningkat yang selanjutnya membuatnya tambah aktif, dan juga menarik anggota-anggota baru.

Berdasarkan uraian di atas, maka peneliti tertarik untuk menuangkan hasil pemikiran dalam bentuk penelitian yang berjudul: "Analisis Komitmen Dan Kompetensi Sumber Daya Manusia Terhadap Perkembangan Koperasi Simpan Pinjam Bahari Jaya Di Kota Jambi”.

\section{TINJAUAN PUSTAKA}

\section{Koperasi}

Undang-Undang RI nomor 17 tahun hukum yang didirikan oleh orang perseorangan atau badan hukum koperasi, dengan pemisahan kekayaan para anggotanya sebagai modal untuk menjalankan usaha, yang memenuhi aspirasi dan kebutuhan bersama di bidang ekonomi, sosial, dan budaya sesuai dengan nilai dan prinsip koperasi."

Konsep Koperasi yang saat ini banyak dianut oleh beberapa negara adalah Koperasi menurut Aliansi Koperasi Sedunia (International Cooperation Alliancel ICA). Pengertian koperasi menurut ICA adalah perkumpulan otonom dari orang yang bersatu secara sukarela 
untuk memenuhi kebutuhan-kebutuhan dan aspirasi aspirasi ekonomi, sosial, budaya melalui perusahaan yang mereka kendalikan secara demokratis. ICA bertindak sebagai lembaga yang menyatukan gerakan-gerakan koperasi di tiap-tiap negera di dunia agar terjadi keseragaman tertutama dalam hal cara memandang jati diri koperasi yang sejati agar dapat berjalan selaras dan sepadan antar negara. Koperasi bekerja berdasarkan beberapa prinsip.

Prinsip-prinsip koperasi yang dikeluarkan ICA dalam Munker (1997) sebagai bagian dari jati diri koperasi dunia adalah 1) keanggotaan sukarela dan terbuka, 2) pengawasan secara demokratis oleh anggota, 3) partisipasi ekonomi anggota, 4) otonomi dan kemandirian, 5) pendidikan dan pelatihan, 6) kerja sama antar koperasi, dan 7) peduli terhadap masyarakat.

Koperasi menurut UUD No. 25 Tahun 1992 yaitu: Koperasi adalah badan usaha yang beranggotakan orang-orang atau badan hukum koperasi dengan melandaskan kegiatan berdasarkan prinsip koperasi sekaligus sebagai gerakan ekonomi rakyat yang berdasar atas azaz kekeluargaan.
Koperasi menurut Bung Hatta yaitu : Orang-orang yang bergabung dan melakukan usaha bersama atas dasar prinsip-prinsip koperasi, sehingga mendapatkan manfaat yang lebih besar dengan biaya yang rendah melalui perusahaan yang dimiliki dan diawasi secara demokratis oleh anggotanya.

Berdasarkan dari beberapa penjelasan diatas maka dapat disimpulkan bahwa koperasi merupakan kumpulan orang-orang memiliki tujuan yang sama dan nasib yang sama, berkumpul melakukan sesuatu dengan tujuan untuk meningkatkan taraf hidup yang lebih baik.

\section{Koperasi Simpan Pinjam}

Menurut Ninik Widiyanti (2003) : "Simpan Pinjam merupakan suatu usaha yang melakukan pembentukan modal melalui tabungan para anggota secara teratur dan terus menerus kemudian dipinjamkan kembali kepada para anggota dengan cara yang mudah, murah, cepat, tepat untuk tujuan produktif dan kesejahteraan".

Koperasi Simpan Pinjam Menurut Peraturan Pemerintah ialah kegiatan usaha simpan pinjam adalah kegiatan yang dilakukan untuk menghimpun dana dan menyalurkannya melalui kegiatan usaha 
simpan pinjam dari dan untuk anggota koperasi yang bersangkutan, calon anggota koperasi yang bersangkutan, koperasi lain dan atau anggotanya.

Menurut (Rudianto: 2006) Koperasi Simpan Pinjam adalah koperasi yang kegiatannya untuk menghimpun dana dan menyalurkanmelalui kegiatan simpan pinjamdari dan urntuk anggota koperasi yang bersangkutan, calon anggota koperasi yang bersangkutan, koperasi lain dan atau anggotanya.

Menurut ( Burhanudin : 2010) Koperasi Simpan Pinjam adalah koperasi yang didirikan guna memberikan kesempatan kepada para anggotanya untuk memperoleh pinjaman atas dasar kebaikan.

Koperasi simpan pinjam memiliki tujuan untuk mendidik anggotanya hidup berhemat dan juga menambah pengetahuan anggotanya terhadap perkoperasian untuk mencapai tujuannya, koperasi simpan pinjam harus melaksanakan aturan mengenai peran pengurus, pengawas, manajer dan yang paling penting, rapat anggota. Pengurus berfungsi sebagai pusat pengambil keputusan tinggi, pemberi nasehat dan penjaga berkesinambungannya organisasi dan sebagai orang yang dapat dipercaya. Menurut UU No.25 tahun 1992, pasal 39, pengawas bertugas melakukan pengawasan terhadap pelaksanaan kebijaksanaan dan pengelolaan koperasi dan menulis laporan koperasi, dan berwewenang meneliti catatan yang ada pada koperasi, mendapatkan segala keterangan yang diperlukan dan seterusnya. Untuk manajer koperasi simpan pinjam juga seperti manajer di organisasi apapun, harus memiliki ketrampilan eksekutif, kepimpinan, jangkauan pandangan jauh ke depan dan mememukan kompromi dan pandangan berbeda. Akan tetapi, untuk mencapai tujuan, rapat anggota harus mempunyai kekuasaan tertinggi dalam organisasi koperasi. Hal ini ditetapkan dalam pasal 22 sampai pasal 27 UU no.25 tahun 1992.

Dari beberapa penjelasan para ahli diatas maka dapat didimpulkan bahwa koperasi simpan pinjam merupakan suatu wadah kegiatan masyarakat yang mana didalamnya terjadi kegiatan yang dilakukan oleh anggotanya didalam menghimpun dana dan menyalurkannya lebih mengutamakan para anggotanya.

\section{Koperasi Simpan Pinjam Bahari Jaya}

Koperasi Bahari Jaya berkedudukan di Telanai Pura Jambi, merupakan Koperasi yang telah berbadan hukum dengan Surat Keputusan No. 
20/BH/VII.10/2011. Koperasi mulai melakukan kegiatan operasional secara aktif melalui Unit Simpan Pinjam sejak tahun 2011.

Adapun visi dan misi dari Koperasi Bahari Jaya adalah:

Visi: Menjadikan Koperasi yang mandiri dengan mengedepankan pelayanan terbaik di dalam membangun dan mengembangkan potensi ekonomi rakyat.

Misi : Meningkatkan kinerja koperasi yang sehat memberikan pelayanan terbaik kepada anggota atau calon anggota.

Produk dan layanan yang dihasilkan oleh Koperasi Bahari Jaya antara lain sebagai berikut :

a) Simpanan Usaha Mandiri Merupakan Simpanan yang ditarik sewaktu waktu dengan kemudahan pelayanan di kantor maupun di tempat usaha.

b) Simpanan Siswa Cendikia

Produk simpanan terencana yang ditujukan untuk mempersiapkan masa depan dana pendidikan anak.

c) Tabungan Hari Raya

Produk simpanan terencana yang ditujukan untuk mempersiapkan apapun hari raya anggota atau calon anggota d) Simpanan Berjangka

Simpanan berjangka yang memberikan jasa setiap bulannya sesuai dengan kesepakatan koperasi tentunya dengan jasa yang relatif tinggi dapat dijadikan fasilitas jaminan untuk kebutuhan pembiayaan anggota.

\section{Komitmen}

Komitmen menurut Young and Denise (1995) menggunakan istilah komitmen ekonomi sebagai pembeda dalam komitmen dalam berorganisasi. Dalam kontek berorganisasi, komitmen didefinisikan sebagai kekuatan relatif individu dalam melibatkan dirinya dengan organisasi (Mowday dalam Boyle, 1997). Lebih lanjut Boyle mengungkapkan bahwa komitmen dapat dikarakteristikkan dalam tiga dimensi, yaitu :

1. Keyakinan yang kuat akan misi dan tujuan organisasi

2. Kemauan untuk berkorban demi tujuan organisasi

3. Memiliki keinginan untuk membina hubungan jangka panjang dengan organisasi

Ketiga dimensi tersebut tidak hanya tampak dalam bentuk perilaku yang nyata namun juga perlu tertanam dalam perasaan. 
Komitmen dalam organisasi merupakan tingkat sejauh mana individu memihak pada suatu organisasi tertentu dan tujuan-tujuannya, serta berniat mempertahankan keanggotaannya dalam organisasi tersebut. Komitmen organisasi dapat tumbuh disebabkan karena individu memiliki ikatan emosional terhadap organisasi yang meliputi dukungan moral dan menerima nilai yang ada dalam organisasi serta tekad dari dalam diri untuk mengabdi pada organisasi (Porter dalam Rahman, 2002). Komitmen yang kuat di dalam diri individu akan menyebabkan individu berusaha keras mencapai tujuan organisasi sesuai dengan tujuan dan kepentingan organisasi (Angel dan Perry; dan Porter, dalam Rahman, 2002).

Komitmen menurut soekidjian (2009) yaitu kemampuan untuk menyelaraskan perilaku pribadi dengan kebutuhan, prioritas dan tujuan organisasi. Hal ini mencakup cara-cara mengembangkan tujuan atau memenuhu kebutuhan organisasi yang intinya mendahulukan misi organisasi daripada kepentingan pribadi.

Dari beberapa penjelasan para ahli diatas maka dapat disimpulkan bahwa komitmen yaitu merupakan suatu sikap keteguhan hati atau kekuatan mental dalam melakukan sesuatu yang mengedepankan rasa tanggung jawab yang tinggi dan diikuti dengan mengedepankan kepentingan kelompok diatas kepentingan pribadi.

\section{Kompetensi Sumber Daya Manusia (SDM)}

Pengertian sumber daya manusia dalam koperasi menurut (Joesron,2005) adalah sumber daya atau potensi. Atau kekuatan, atau kemampuan yang ada dalam diri manusia, yang menentukan sikap dan kualitas manusia untuk dapat berprestasi dan menjadikan organisasinya tetap hidup dan mampu bersaing.

Menurut Harmein Nasution, bahwa sumber daya manusia (SDM) di dalam organisasi merupakan kunci keberhasilan organisasi, karena pada dasarnya SDM yang merancang, memasang, mengoperasikan dan memelihara dari system integral tersebut, baik itu input, proses, maupun output. Manusia sebagai asset yang akan mengelola sumber daya yang ada dalam organisasi memerlukan manusia yang baik kualitasnya. Sumber daya manusia jika ditinjau dari segi kualitasnya memiliki dua kemampuan, yaitu : 
1) Hard Skill : Kemampuan akademik yang dimiliki seseorang.

2) Soft Skill : Kemampuan menyesuaikan dengan lingkungan terutama dalam dunia kerja / organisasi.

Kedua kemampuan di atas diperlukan bagi sumber daya manusia dalam menggerakkan dan mengembangkan organisasi. Agar kualitas sumber daya manusia yang dihasilkan memenuhi standar maka setiap tahapan proses harus direncanakan dan dikendalikan sesuai dengan standard dan spesifikasi yang telah ditetapkan sesuai kebutuhan organisasi.

Kompetensi didefinisikan oleh Mitrani (1995) sebagai suatu sifat dasar seseorang yang dengan sendirinya berkaitan dengan pelaksanaan suatu pekerjaan secara efektif (and underlying charactheristic: of an individual which is casually related to effective or superior performance in job), Ketidaksamaan dalam kompetensi-kompetensi inilah yang membedakan seseorang pelaku unggul dari perilaku yang berprestasi rata-rata. Kompetensi erat kaitannya dengan kinerja, baik kinerja individu maupun kinerja organisasi (perusahaan).

Kompetensi SDM Koperasi Simpan Pinjam dalam penelitian ini memfokuskan pada tiga hal pokok yaitu: Pengetahuan (Knowladge), Keterampilan (Skill) dan Kemampuan (Ability), Pengetahuan (Knowladge), merupakan penguasaan ilmu dan teknologi yang dimiliki seseorang, dan diperoleh melalui proses pembelajaran serta pengalaman selama kehidupannya (Rohman, 2016). Indikator pengetahuan (knowladge) antara lain pengetahuan manajemen dalam bisnis, pengetahuan tentang produk atau jasa, pengetahuan tentang konsumen, promosi dan strategi pemasaran.

Keterampilan (Skill), adalah kapasitas khusus untuk memanipulasi suatu objek secara fisik. Indikator keterampilan meliputi: keterampilan berkomunikasi, ketrampilan kerjasama dan organisasi, pengawasan, keuangan, administrasi dan akuntansi. Kemampuan (Ability), adalah kapasitas seorang individu untuk mengerjakan berbagai tugas dalam suatu pekerjaan. Indikator kemampuan meliputi: kemampuan mengelola bisnis, kemampuan dalam mengambil keputusan, kemampuan sebagai pemimpin, kemampuan dalam berinovasi dan perubahan lingkungan bisnis. 


\section{Masalah Koperasi Dan Sumber Daya Manusia Koperasi}

Koperasi adalah salah satu mekanisme penting untuk memasuki pasar. Menurut Peter Devis (1999), dalam bukunya "managing the cooperative difference" dalam banyak hal ini koperasi banyak berjuang untuk bersaing dengan satu lebih alasan sebagai berikut.

1) Terdapat tumpang tindih pelayanan dan fungsi didalam gerakan koperasi, karena koperasi tidak melakukan merger dan konsolidasi yang cukup cepat untuk menyesuaikan diri terhadap lingkungan yang kompetitif.

2) Koperasi berkembang secara lambat di dalam sektor bisnis dan informasi yang secara teknologi berkembang secara cepat.

3) Hanya sedikit koperasi primer yang beroperasi secara nasional atau bahkan masuk ke dalam perdagangan internasional.

4) Kebanyakan koperasi beroperasi dengan" value added" yang rendah ketika terkait dalam rantai jaringan bisnis atau industri.

5) Koperasi dicirikan oleh sangat rendahnya semangat kewirausahaan atau budaya, sehingga menyebabkan hilangnya peluang dan rendahnya inovasi.

Koperasi kekurangan komitmen atau keadaan terhadap kebutuhan untuk mengembangkan manajemen eksekutif dan pada umumnya tidak menyadari peran krusial kepemimpinan di dalam memperjuangkan dan mempertahankan tujuan dan nilai-nilai koperasi. Masalah utama sumber daya manusia koperasi terletak bukan pada kuantitas tetapi pada kualitas. Masalah kualitas pada dasarnya adalah akibat dari masih lemahnya menejemen porsonalia di koperasi.

\section{METODE PENELITIAN}

Penelitian ini merupakan penelitian deskriptif kualitatif fokusnya adalah penggambaran secara menyeluruh tentang bentuk, fungsi, ungkapan larangan, dan penelitian yang menggambarkan atau menjelaskan permasalahan yang diteliti dalam bentuk kalimat dan bukan dalam angka-angka, kemudian dianalisis dengan menggunakan asumsi dan kajian teori. Menurut Djma'an dan Aan komariah (2011:25) pendekatan kualitatif adalah suatu pendekatan penelitian yang mengungkapkan situasi social tertentu dengan mendeskripsikan kenyataan secara benar, dibentuk oleh kata-kata berdasarkan 
teknik pengumpulan data yang relevan diperoleh dari situasi alamiah.

Waktu penelitian dilakukan selama satu bulan, yaitu pada bulan November 2018 Penelitian ini adalah penelitian Studi Kasus/Survey yang dilaksanakan di Koperasi Simpan Pinjam Bahari Jaya Perum Aurduri Blok F Kelurahan Penyengat rendah Kecamatan Telanai Pura Jambi. Informan dalam penelitian ini adalah petugas Koperasi Bahari jaya. Untuk melengkapi hasil penelitian ini, maka dilakukan pengumpulan data dengan menggunakan metode studi kepustakaan, wawancara, dan observasi ke lapangan. Data dari survey yang kami lakukan adalah data primer yang berasal dari tanya jawab langsung terhadap petugas Koperasi Bahari jaya. Data sekunder berupa laporan perkembangan Koperasi Bahari jaya.

\section{HASIL DAN PEMBAHASAN}

\section{Komitmen Mempengaruhi \\ Perkembangan Koperasi Simpan Pinjam di Kota Jambi}

\section{Setiap pengurus Koperasi}

harus memiliki idealisme dengan dasar moral yang baik. Dengan idealisme itulah mereka akan memiliki komitmen yang baik terhadap perkoperasian. Dalam hal ini, anggota dan pengurus, pengawas maupun pembina koperasi harus memiliki komitmen yang baik terhadap hakikat koperasi, tujuan positif, peraturan dan pengembangannya. Komitmen ini adalah modal dasar untuk bisa dikelola dan dikembangkannya koperasi secara baik dan benar, serta memberi manfaat bersama, sehingga diharapkan anggota, pengelola, pengawas dan pembina koperasi dapat selalu :

a) Memiliki semangat untuk selalu memajukan koperasi dan bertanggungjawab secara penuh demi kemajuan koperasi.

b) Mengedepankan moral dan mental yang baik dalam kehidupan seharihari. Terlebih saat menjadi anggota, pengurus, pengawas maupun pembina koperasi.

c) Menghindarkan diri dari perbuatan tercela atau hal-hal yang dapat merusak jati diri koperasi.

d) Melakukan penggalangan anggota yang lebih banyak dan berkualitas yang didasarkan pada kesadaran untuk berkoperasi.

e) Profesionalismenya pengurus dalam pengelolaan koperasi 
(manajemen) dan membaca tuntutan zaman yang ada.

Komitmen dalam jangka panjang, menunjukkan adanya hubungan yang saling menguntungkan antara anggota dalam Koperasi. Penelitian oleh Mowdey dalam Boyle mengatakan bahwa komitmen tidak hanya tampak dalam perilaku nyata, namun hendaknya benar-benar muncul dari kedalaman hati. Koperasi bahari Jaya selalu berusaha menjadi koperasi yang mandiri dan profesional dalam mewujudkan dan mengembangkan potensi dan kemampuan ekonomi anggota, khususnya masyarakat umumnya. Dengan adanya komitmen dalam Koperasi maka diharapkan semua pengurus koperasi akan meningkatkan kinerjanya sesuai dengan tujuan Koperasi. Sehingga perkembangan koperasi menjadi lebih baik.

Komitmen yang tinggi yang dimiliki oleh para anggota koperasi sangat mempengaruhi terhadap perkembangan koperasi di koperasi simpan pinjam Bahari Jaya maka dengan ini dapat disimpulkan bahwa semakin tinggi nilai sikap anggota koperasi maka perkembangan koperasi semakin maju dan begitu sebaliknya.

\section{Kompetensi Sumber Daya Manusia (SDM) \\ Mempengaruhi}

\section{Perkembangan Koperasi Simpan Pinjam di Kota Jambi}

Sehubungan dengan masalah sumber daya manusia ini, sebenarnya telah cukup banyak langkah yang telah ditempuh oleh pemerintah untuk mengembangkan sumber daya koperasi. Sebagai contoh adalah penyuluhan tentang koperasi, penyelenggaraan pendidikan dan pelatihan bagi pihak-pihak yang terkait dengan gerakan koperasi. Kompetensi Sumber Daya Manusia (SDM) Koperasi Simpan Pinjam dalam penelitian ini memfokuskan pada tiga hal pokok yaitu: Pengetahuan (Knowladge), Keterampilan (Skill) dan Kemampuan (Ability), Pengetahuan (Knowladge), merupakan penguasaan ilmu dan teknologi yang dimiliki seseorang, dan diperoleh melalui proses pembelajaran serta pengalaman selama kehidupannya (Rohman, 2016). 


\begin{abstract}
Kompetensi sumberdaya manusia mempengaruhi perkembangan Koperasi Bahari Makmur yang dilihat dari tiga indikator yaitu, (1) indikator pengetahuan (knowladge) antara lain pengetahuan manajemen dalam bisnis diharapkan para anggota Koperasi Bahari Jaya memiliki pengetahuan dalam mengelola Koperasi berupa Produk dan layanan yang ada pada koperasi Bahari Jaya. (2) Indikator Keterampilan (Skill) meliputi: keterampilan berkomunikasi, ketrampilan kerjasama dan organisasi, pengawasan, keuangan, administrasi dan akuntansi. Dengan adanya Ketrampilan yang dimiliki oleh pengurus Koperasi maka diharapkan adanya perbaikan kearah yang lebih baik bagi Koperasi Bahari Jaya. (3) Indikator Kemampuan (Ability) meliputi: kemampuan mengelola bisnis, kemampuan dalam mengambil keputusan, kemampuan sebagai pemimpin, kemampuan dalam berinovasi dan perubahan lingkungan bisnis. Diharapkan dengan adanya kemampuan yang dimiliki oleh pengurus Koperasi sehingga perubahan di dalam koperasi akan
\end{abstract}

semakin baik dan perkembangan koperasi kedepannya semakin bagus. Sumberdaya manusia yang dimiliki merupakan salah satu faktor yang sangat penting di dalam neingkatkan kualitas kerja seseorang maka dengan ini sumberdaya manusia sangat berpengaruh terhadap perkembangan koperasi simpan pinjam Bahari Jaya kedepannya dan begitu juga sebaliknya.

\section{PENUTUP}

\section{Kesimpulan}

Koperasi Simpan Pinjam didirikan bertujuan untuk memberi kesempatan kepada anggotanya untuk memperoleh pinjaman dengan mudah dan dengan bunga ringan. Koperasi simpan pinjam juga berusaha untuk mencegah para anggotanya agar tidak terlibat dalam jeratan kaum lintah darat pada waktu mereka memerlukan sejumlah uang, dengan jalan menggiatkan tabungan dan mengatur pemberian pinjaman uang dengan bunga yang serendah-rendahnya, Koperasi simpan pinjam menghimpun dana dari para anggotanya yang kemudian menyalurkan kembali dana tersebut kepada para anggotanya. Didalam Koperasi Bahari Jaya Komitmen sangat diperlukan bagi setiap 
petugas koperasi karena dengan adanya komitmen yang tinggi akan berdampak terhadap perkembangan Koperasi dan begitu juga dengan Kompetensi Sumber Daya Manusia juga harus dimiliki oleh setiap petugas koperasi hal ini dikarenakan Kompetensi sangat mempengaruhi perkembangan koperasi.

\section{Saran}

Sebaiknya kopersai perlu ditingkatkan dan dikembangkan dengan banyak pelatihan yang diberikan utamanya kepada pengurus koperasi sehingga dapat membuat kinerja dan dan pelayanan yang diberikan lebih baik dengan demikian akan semakin banyak msyarakat yang tertarik untuk berkoperasi, dan juga sisoalisasi ke masyarakat tentang pendidikan koperasi agar masyarakat mau bergabung dengan koperasi yang tidak lain bertujuan untuk meningkatkan kesejahteraan masyarakat itu sendiri. tentunya hal ini diperlukan juga perhatian yang serius dari pemerintah khusunya instansi yang terkait untuk mengajak masyarakat masuk menjadi anggota Koperasi. Kepada anggota koperasi untuk lebih aktif berpartisipasi dalam koperasi sebagai usaha yang dikerjakan secara barsama-sama dan untuk kepentingan bersama pula.

\section{DAFTAR PUSTAKA}

Ali M, 2002, Penerapan Analisis Rasio Keuangan Sebagai Tolak Ukur Penilaian pada Badan Usaha Berbetuk Koperasi, Jurnal Universitas Paramadina Volume 1 no.3.

Febri Karauwan, 2011, Pengukuran Kinerja Perusahaan Menggunakan Metode Performance Prism pada PT Tunas Dwipa Matra, Jurnal Universitas Sam Ratulangi vol 1 no.1

ICA. 2009. International Co-operative Aliiance - $\quad$ Rules. http://www.ica.coop/al-ica. (2009)

Hasibuan, M. S. 2009. Manajemen Sumber Daya Manusia. Jakarta: Bumi Aksara.

Ikhsan, Arfan, dan La Ane, (2007), "Pengaruh Partisipasi Anggaran terhadap Senjangan Anggaran dengan Menggunakan Lima Variabel Moderasi”, Makalah dalam Simposium Nasional Akuntansi X.

Mulyadi, (2001), "Akuntansi Manajemen: Konsep, Manfaat, dan Rekayasa", Yogyakarta: BP STIE YKPN

Niniek Widyati, 2010, Evaluasi Kinerja yang Diukur dengan Rasio untuk 
Mengetahui Tingkat Kesehatan

Koperasi (Studi Kasus pada

Koperasi Pegawai Republik

Indonesia-Rumah Sakit dr. Saiful

Anwar Malang), Skripsi, Fakultas

Ekonomi \& Bisnis Universitas

Brawijaya, Malang.

Rohman, Fatchur. 2016. Kompetensi Sdm Dan Pengaruhnya Terhadap Kinerja Karyawan Bagian Akuntansi Ksp Di Kabupaten Jepara. JEAM Vol XV April 2016.

Sugiyono. 2007. Metode Penelitian Pendidikan. Bandung: Alfabeta.

Sutama. 2010. Metode Penelitian Pendidikan kuantitatif dan kualitatif. Surakarta: Fairuz Media.

Undang-Undang Republik Indonesia No. 17 Tahun 2012 tentang Perkoperasian.

Young, L, Denize, S,. 1995. A Concept of Commitment: Alternative Views of Relational Continuity in Business Services Relationship. Journal of Business \& Industrial Marketing, Vol. 10, No.5, 22-37. 